\section{$\AA ̊$ drive allmennpraksis}

er som å dirigere et symfoniorkester. Samtidig som du selv spiller fløyte og harpe. Og får beskjed om at oboen ikke har tid akkurat nå. Og at det er seks måneders ventetid på paukeslag. Mens publikum roper på «Livet på Finnskogen». Og ber deg bestille drosje hjem...

\section{Jon Schumann-Andersen}

kongsten@kongstenlegekontor.nhn.no Fredrikstad

Jon Schumann-Andersen (f. 1950) er spesialist i allmennmedisin og fastlege ved Kongsten legekontor.

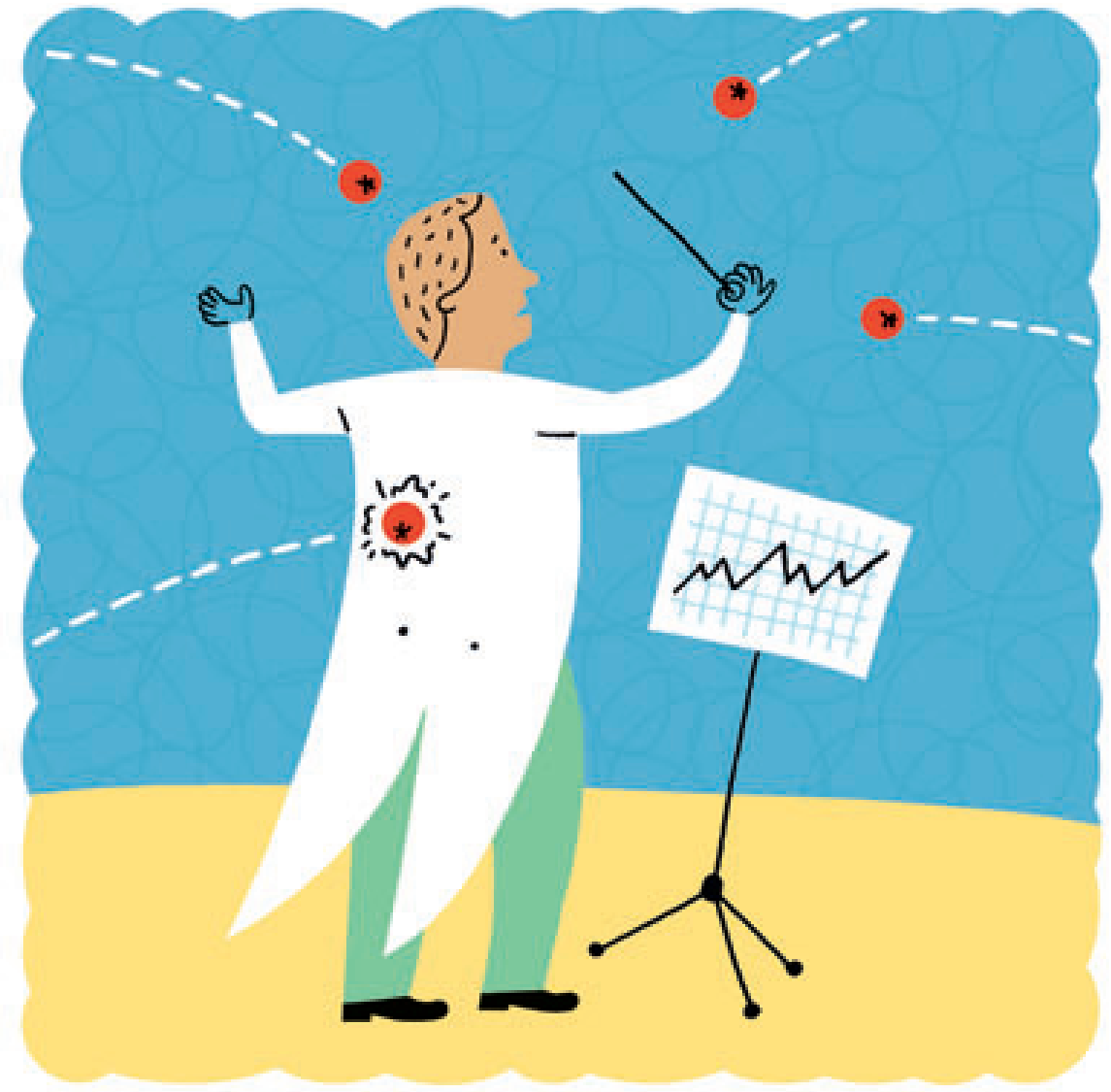

Illustrasjon Svein Størksen

\title{
Utredning ved sterk mistanke om kreft
}

\author{
Noen symptomer og tegn på kreft bør behandles som en øyeblikkelig hjelp-situasjon, \\ med garanti om utredning innen 48 timer.
}

Den siste tiden har det vært stor oppmerksomhet i mediene rundt oppfølging av pasienter som henvises til sykehus med mistanke om kreft. Spørsmålet har også vært debattert politisk, blant annet i spørretimen i Stortinget. Det er blitt påpekt at ventetiden for disse pasientene i mange tilfeller er altfor lang og at de i slike tilfeller skal få tilbud om nærmere utredning innen 48 timer. Bakgrunnen er et enkeltstående tilfelle der det var sterkt forsinket reaksjon på en henvisning fra primærlege for blodig urin over tid. Det gikk over én måned før personen fikk time til utredning, og pasienten døde ett år etter. De pårørende opplevde forholdet til sykehuset lite tilfredsstillende, til dels provoserende. Det førte til et sterkt engasjement fra ektefellen for å få en bedring av rutinene.

Hvilke rutiner er det egentlig som gjelder? Hvorfor blir en pasient med fraktur behandlet som en øyeblikkelig hjelp-pasient, mens en pasient som henvises med sterk mistanke om kreftsykdom må vente i ukevis på tilsyn? Det er neppe noen medisinskfaglig uenighet om at det finnes noen få symptomer og funn som gir så sterk mistanke om kreftsykdom at tilstanden bør behandles som en nær øyeblikkelig hjelp-situasjon. Det er ikke så mange symptomer og tegn det gjelder, egentlig bare to hovedgrupper:

- Blødninger: hematuri, hemoptyser, vedvarende blod i avføring

- Svulster/ kuler: på halsen, i aksiller eller i mammae, i lysken, i testis og påtakelige forandringer ved føflekk

Det må altså være objektive funn til stede, og primærlegen må i henvisningen presisere at det er så sterk mistanke om kreft at hurtig utredning må til innen 48 timer. Med så klare kriterier kan ingen snike i pasientkøen, noe enkelte leger har uttrykt frykt for

Det bør være en del av det legeetiske ansvaret å sørge for at det blir igangsatt utredning innen 48 timer. Dette forutsetter selvsagt at avdelingsoverlegen har kontroll med hva som henvises (leser posten!!) og ikke har delegert denne viktige oppgaven til andre, f.eks oversykepleier - eller at han har mistet denne oppgaven i en omorganisering som har til hensikt nettopp å fjerne legene fra administrative stillinger. I begge tilfeller må han/hun som avdelingens øverste medisinskansvarlige sørge for at ingen i denne pasientgruppen forsvinner inn på uoversiktlige ventelister. Det kan bare skje ved selv å lese alle henvisninger.

Det er jo ikke veldig ressurskrevende utredninger. Det kan dreie seg om skopier (bronko-, cysto-, koloskopier) og/eller cytologiske prøver eller røntgenologiske undersøkelser. For en del av disse pasientene vil det vise seg at de ikke har noen kreftsykdom, men for dem som får bekreftet mistanken, vil den tidlige diagnosen også føre til en tidligere behandling. Som Aftenposten skriver i sin leder 23.5. 2011: «Kan Danmark få det til, burde også vi klare det.» Vi som leger må i alle fall ikke stille oss negative, vår legeetikk forplikter oss.

Sølve Hognestad

shogn@online.no

Ragnhildsgate 21, 4044 Hafrsfjord

Sølve Hognestad (f. 1932) er spesialist

i øre-nese-halssykdommer.

Ingen oppgitte interessekonflikter. 